\title{
USULAN PERANCANGAN ALAT BANTU UNTUK MENGURANGI RISIKO CEDERA MUSCULOSKELETAL PADA PEKERJA DI CV. XYZ
}

\author{
Armijal $^{1}$, Dini Wahyuni ${ }^{2}$, Mangara Tambunan ${ }^{2}$ \\ ${ }^{1}$ Staf Pengajar Departemen Teknik Industri Universitas Teuku Umar (UTU) \\ Email : Armijalna@gmail.com \\ ${ }^{2}$ Staf Pengajar Departemen Teknik Industri Universitas Sumatera Utara (USU)
}

\begin{abstract}
Workers involving in a manual task (e.g. lifting, pushing, pulling, etc.) are subject to a musculoskeletal disorders (MSDs) risk. The risk is even worse should the workers are not working in a good body posture while facilities and working environment are not ergonomically designed. Thus, it becomes significant for the workers to have a normal body posture while performing tasks. In addition, they also should be equipped with facilities and working environments that are ergonomically designed. $C V . X Y Z$ is a garment industry which produces apparels and other clothes. $C V . X Y Z$ has several work stations, and one of them is a film-making (screen printing) station. There are 20 work elements in this station, where all of them are a manual task. This research aims to investigate and evaluate over working condition, facilities and working environment at film-making station which later will be quantified into MSDs risk level. For this purpose, this research will employ Rapid Entire Body Analysis (REBA) to measure MSDs risk of the worker in this station. From this evaluation, it will suggest a creation of ergonomic aid tools which aims to reduce the risk of MSDs level. Those aid tools are a desk, a chair and a lorry that are designed by considering body posture and anthropometry principles. A simulation analyisis will be performed by using a mannequin pro software so that the comparison of the MSDs risk level prior and after the improvement can be obtained. Research finding shows that after implementing the suggested solution, 15 out of 20 work elements show a reduction of REBA score, and lowering the risk of MSDs.
\end{abstract}

Keywords: Musculoskeletal disorder (MSDs), Rapid Entire Body Assesment (REBA), Manual tasks, manual material handling (MMH), ergonomic-designed, anthropometry. 


\section{Pendahuluan}

Pekerjaan manual (manual task) dapat diartikan sebagai pekerjaan yang meliputi kegiatan mengangkat (lifting), mendorong (pushing), menarik (pulling), membawa (carrying), memindahkan (moving), atau memegang (holding) suatu benda/item. Ansari dan Sheikh (2014) mengatakan beberapa pekerjaan manual dilakukan dengan cara yang berbahaya yang dapat menyebabkan keluhan yang biasa disebut dengan musculoskeletal disorders (MSDs). Siddiqui dan Chacko (2015) menyebutkan bahwa resiko MSDs merupakan masalah utama dalam pekerjaan baik di negara maju maupun berkembang yang mana resiko tersebut akan berimbas kepada tingginnya biaya kompensasi kerja dan kesehatan, penurunan produktivitas, dan penurunan kesejahteraan hidup.

Istighfaniar dan Mulyono (2016) pernah meneliti tentang keluhan MSDs yang dialami oleh pekerja di bagian instalasi farmasi salah satu poliklinik kesehatan di Madiun. Mereka menemukan bahwa penyebab utama keluhan tersebut adalah sikap kerja tidak alamiah, pekerjaan berulang-ulang dan dalam jangka waktu yang lama, serta posisi yang tidak ergonomis. Simanjuntak (2007) juga meneliti tentang keluhan MSDs pekerja pada perusahaan yang menghasilkan produk bermacam-macam tas. Peneliti tersebut menyarankan perlunya perbaikan perancangan kerja dan penataan tempat kerja yang ergonomis untuk meminimalkan risiko cedera MSDs. Penelitian lainnya yang membahas tentang keluhan MSDs terkait pekerjaan manual juga dilakukan oleh Anggraini dan Pratama (2012) yang meneliti pada industri pengolahan karet. Peneliti tersebut menemukan adanya keluhan MSDs yang dialami operator bagian pengepakan sebesar $33 \%$ dan menyarankan penggunaan ring conveyor untuk menurunkan keluhan tersebut.

CV. XYZ merupakan sebuah usaha konveksi pakaian olahraga yang terdiri atas beberapa stasiun kerja yang salah satunya adalah stasiun pembuatan film (sablon). Stasiun ini memiliki 20 elemen gerakan kerja manual di mana elemen kerjanya yang paling beresiko adalah kegiatan mengangkat pemberat dari lantai ke meja kerja serta menurunkannya kembali ke lantai. Pemberat tersebut berbeban $150 \mathrm{~N}$, dan posisi operator membungkuk hampir $90^{\circ}$. Pekerjaan tersebut dilakukan secara repetitif dengan jam kerja normal 8 jam per hari. Pengamatan pendahuluan dengan menyebarkan kusioner SNQ, diperoleh bahwa operator tersebut merasakan keluhan sakit sebesar $57 \%$ dan keluhan sangat sakit sebanyak $11 \%$. Hal ini mengindikasikan adanya keluhan musculoskeletal yang dirasakan operator.

Dalam upaya meminimumkan kelelahan serta risiko cedera tulang dan otot saat bekerja, maka diperlukan perancangan fasilitas dan stasiun kerja seergonomis mungkin. Penelitian ini ditujukan untuk mengevaluasi dan menganalisis tingkat cedera tulang punggung (MSDs) yang dialami pekerja dengan pendekatan metode REBA. Dari evaluasi tersebut akan dirancang alat bantu ergonomis dengan mempertimbangaka prinsip-prinsip perancangan, antropometri dan postur kerja.

\section{Tinjauan Pustaka}

\section{a. Musculoskeletal Disorders (MSDs)}

Keluhan musculoskeletal adalah keluhan pada bagian-bagian otot skeletal yang dirasakan oleh seseorang mulai dari keluhan sangat ringan sampai sangat sakit (Tarwaka, 2004). Apabila otot menerima beban statis secara berulang dan dalam waktu yang lama, dapat menyebabkan keluhan berupa kerusakan sendi, ligamen, dan tendon. Keluhan hingga kerusakan inilah yang biasa diistilahkan dengan musculoskeletal disorders (MSDs) atau cedera pada sistem musculoskeletal (Tarwaka, 2004).

Secara garis besar keluhan otot dapat dikelompokkan menjadi dua, yaitu keluhan sementara (reversible) dan keluhan menetap (permanent). MSDs dipandang sebagai salah satu masalah utama pada perusahaan dengan alasan berikut:

a. Adanya penurunan produktivitas kerja akibat keluhan MSDs yang diderita oleh operator.

b. Tingginya biaya kompensasi dan kesehatan pekerja karena cedera tulang punggung membutuhkan biaya perawatan yang tinggi

c. Adanya pemborosan waktu kerja oleh operator untuk menyesuaikan tubuhnya dari keluhan rasa sakit tulang belakang.

d. Cedera MSDs bersifat multi-kausal, yang sangat sulit untuk menentukan proporsi cedera yang semata-mata akibat hubungan 
kerja.

\section{b. Faktor Risiko Musculoskeletal Disorders (MSDs) dan Keluhannya}

Lebih lanjut, Tarwaka (2004) menjelaskan bahwa risiko MSDs terkait dengan aktivitas manual material handling (MMH) terdiri atas beberapa faktor yaitu karakteristik pekerjaan, individu (pekerja), material dan lingkungan kerja. Karakteristik pekerjaan meliputi tentang postur kerja, frekuensi, durasi, dan vibrasi. Karakteristik individu meliputi usia, kebiasaan olahraga, masa kerja, kebiasaan merokok, kesegaran jasmani dan dimensi antropometri. Karakteristik material meliputi besar, berat dan bentuk objek. Sementara karekteristik lingkungan kerja meliputi cuaca dan konsentrasi oksigen, serta desain lingkungan kerja.

\section{c. Rapid Entire Body Asssesment (REBA)}

Menurut Hignett dan McAtamney (2000), rapid entire body assessment (REBA) merupakan metode dalam bidang ergonomi yang berfungsi untuk menilai posisi kerja atau postur leher, punggung, lengan, pergelangan tangan dan kaki seorang operator. Siddiqui dan Chacko (2015) menambahkan bahwa REBA merupakan teknik penilaian postur tubuh pekerja yang dikaitkan dengan level risiko cedera tulang punggung (MSDs). Sistem klasifikasi postur tubuh dalam metode ini meliputi tangan bagian atas, tangan bagian bawah, pergelangan tangan, punggung/badan, leher dan kaki. Metode ini memberikan lima level tindakan yang perlu dilakukan dalam mengevaluasi tindakan perbaikan antara lain:

1. Level 0: Tindakan perbaikan, termasuk penilaian lebih lanjut tidak diperlukan.

2. Level 1: Tindakan perbaikan, termasuk penilaian lebih lanjut mungkin diperlukan.

3. Level 2: Tindakan perbaikan, termasuk penilaian lebih lanjut diperlukan.

4. Level 3: Tindakan perbaikan, termasuk penilaian lebih lanjut penting dilakukan segera.

5. Level 4: Tindakan perbaikan, termasuk penilaian lebih lanjut mutlak dilakukan segera.

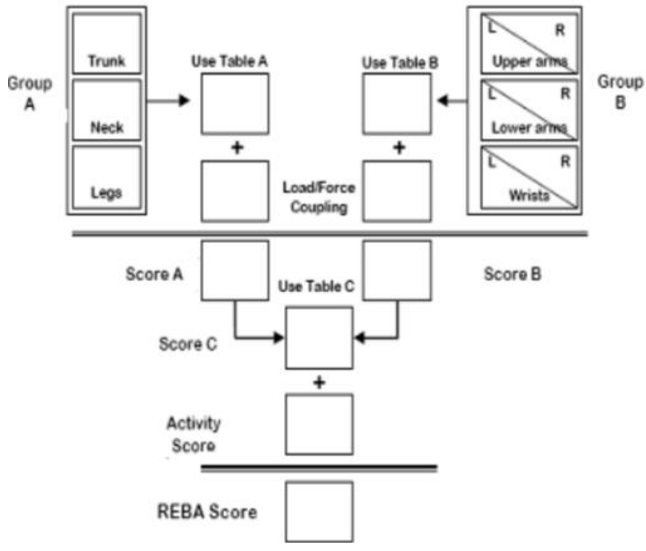

Gambar 1 REBA (Hignett dan McAtamney 2000)

Prinsip kerja penilaian postur kerja dengan metode REBA adalah dengan menggunakan tabel A dan B untuk menentukan Skor grup A dan grup B. Skor grup A diperoleh dengan melakukan observasi pada postur tubuh (meliputi badan, leher dan kaki) pekerja ketika melakukan aktivitas. Sementara itu, skor grup B diperoleh dengan melakukan penilaian postur tubuh (meliputi lengan bagian atas,lengan bagian bawah dan pergelangan tangan) pekerja pada saat dia beraktivitas. Setelah skor A dan B diperoleh, maka keduanya diagregasi untuk mendapatkan skor C dengan merujuk pada Tabel C. Setelah skor C diperoleh, maka skor tersebut diagregasikan kembali dengan skor coupling dan aktivitas (postur tubuh statis, repetitif, perubahan postur tubuh yang tiba-tiba) untuk memperoleh skor akhir REBA.

\section{Metode Penelitian}

Penelitian ini dilakukan di CV. XYZ, Medan, Sumatera Utara. Adapun yang menjadi subjek utama dalam penelitian ini adalah operator pada stasiun pembuatan film (sablon). Stasiun ini dipilih berdasarkan hasil pengamatan pendahuluan dengan menyebarkan kuesioner SNQ yang menyatakan bahwa stasiun ini memiliki keluhan MSDs tertinggi. Peneliti melakukan identifikasi elemen gerakan kerja pada stasiun tersebut dan mengukur sudut gerakan kerja dengan menggunakan teknik photographic measurement (Nierkerk dkk, 2008). Selain itu, peneliti juga melakukan pengukuran terhadap dimensi antropometri operator serta 
melakukan pencatatan dan dokumentasi mengenai fasilitas kerja aktual di stasiun tersebut. Selanjutnya, dekstop research dilakukan untuk menganalisis dan melakukan pengolahan data.

Kerangka konseptual dan blok diagram penelitian ini dapat dilihat pada Gambar 2 berikut:

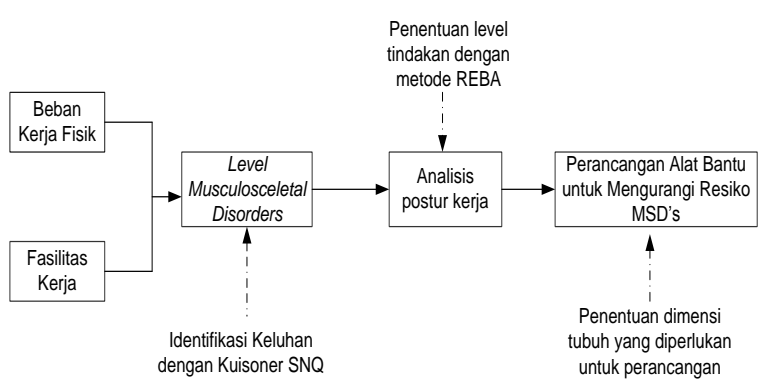

Gambar 2 Kerangka Konseptual Penelitian

Sedangkan blok diagram penelitian disajikan pada Gambar 3 berikut:

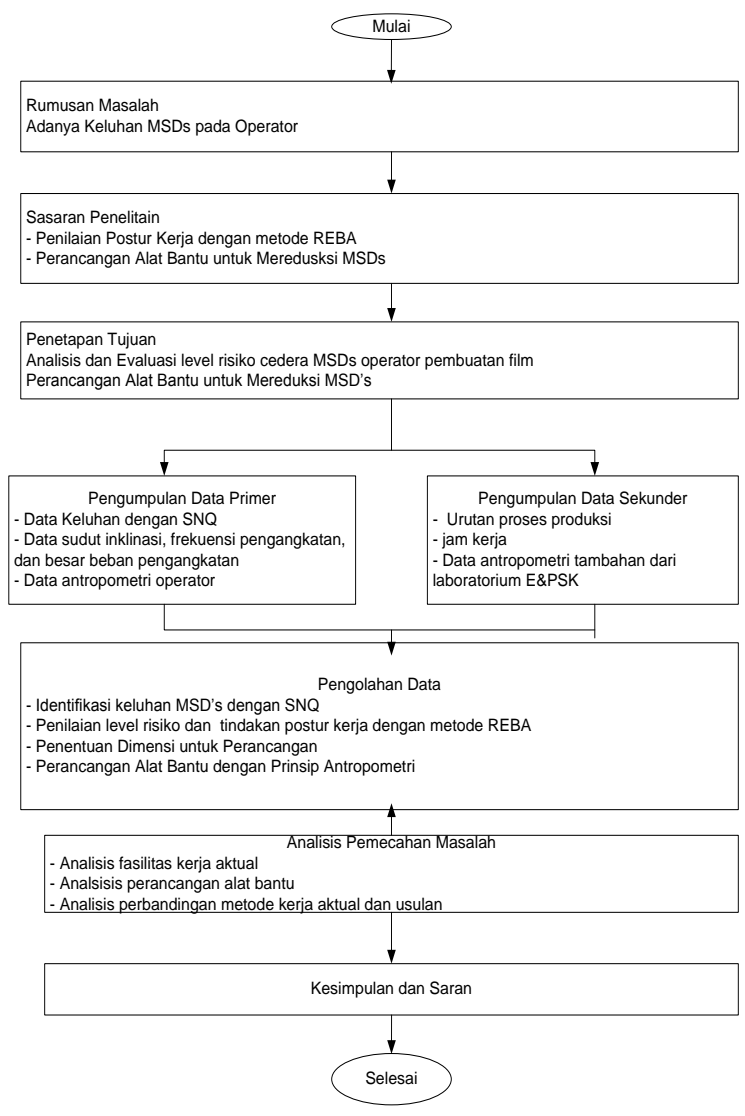

Gambar 3 Blok Diagram Penelitian

Hasil dan Pembahasan
CV. XYZ memiliki 6 stasiun kerja yaitu stasiun pemotongan pola, penjahitan, penyetingan film, pembuatan film (sablon), penyetrikaan dan packing. Kuesioner SNQ disebarkan pada seluruh operator pada masingmasing stasiun kerja tersebut dan diperoleh hasil seperti Tabel 1 di bawah ini

Tabel 1 Rekapitulasi Kuesioner SNQ

\begin{tabular}{|l|l|l|l|}
\hline No & \multicolumn{1}{|c|}{ Nama Stasiun } & \multicolumn{1}{|c|}{$\begin{array}{c}\text { Sakit } \\
(\boldsymbol{\%})\end{array}$} & $\begin{array}{c}\text { Sangat } \\
\text { Sakit } \\
(\%)\end{array}$ \\
\hline 1 & St. pemotongan pola & 10,71 & 0 \\
\hline 2 & St. penjahitan & 24,76 & 2.38 \\
\hline 3 & St. penyetingan film & 7.00 & 0 \\
\hline 4 & St. pembuatan film & 57.00 & 11 \\
\hline 5 & St. penyetrikaan & 21.00 & 0 \\
\hline 6 & St. packing & 7.00 & 0 \\
\hline
\end{tabular}

Stasiun pembuatan film merupakan stasiun dengan keluhan paling tinggi, karenanya penelitian ini difokuskan pada stasiun kerja tersebut. Stasiun kerja tersebut memiliki 20 elemen gerakan kerja seperti yang ditampilkan pada Tabel 2 berikut ini.

Tabel 2 Elemen Gerakan Kerja

\begin{tabular}{|l|l|l|}
\hline No. & $\begin{array}{l}\text { Elemen } \\
\text { Kerja } \\
\text { Meletakkan } \\
\text { kertas } \\
\text { setingan pada } \\
\text { meja kerja }\end{array}$ \\
\hline 2 & $\begin{array}{l}\text { Mengolesi } \\
\text { kertas } \\
\text { setingan } \\
\text { dengan } \\
\text { minyak }\end{array}$ \\
\hline 4 & $\begin{array}{l}\text { Mengambil } \\
\text { obat (ulano) } \\
\text { Mengambil }\end{array}$ \\
\hline screen film
\end{tabular}



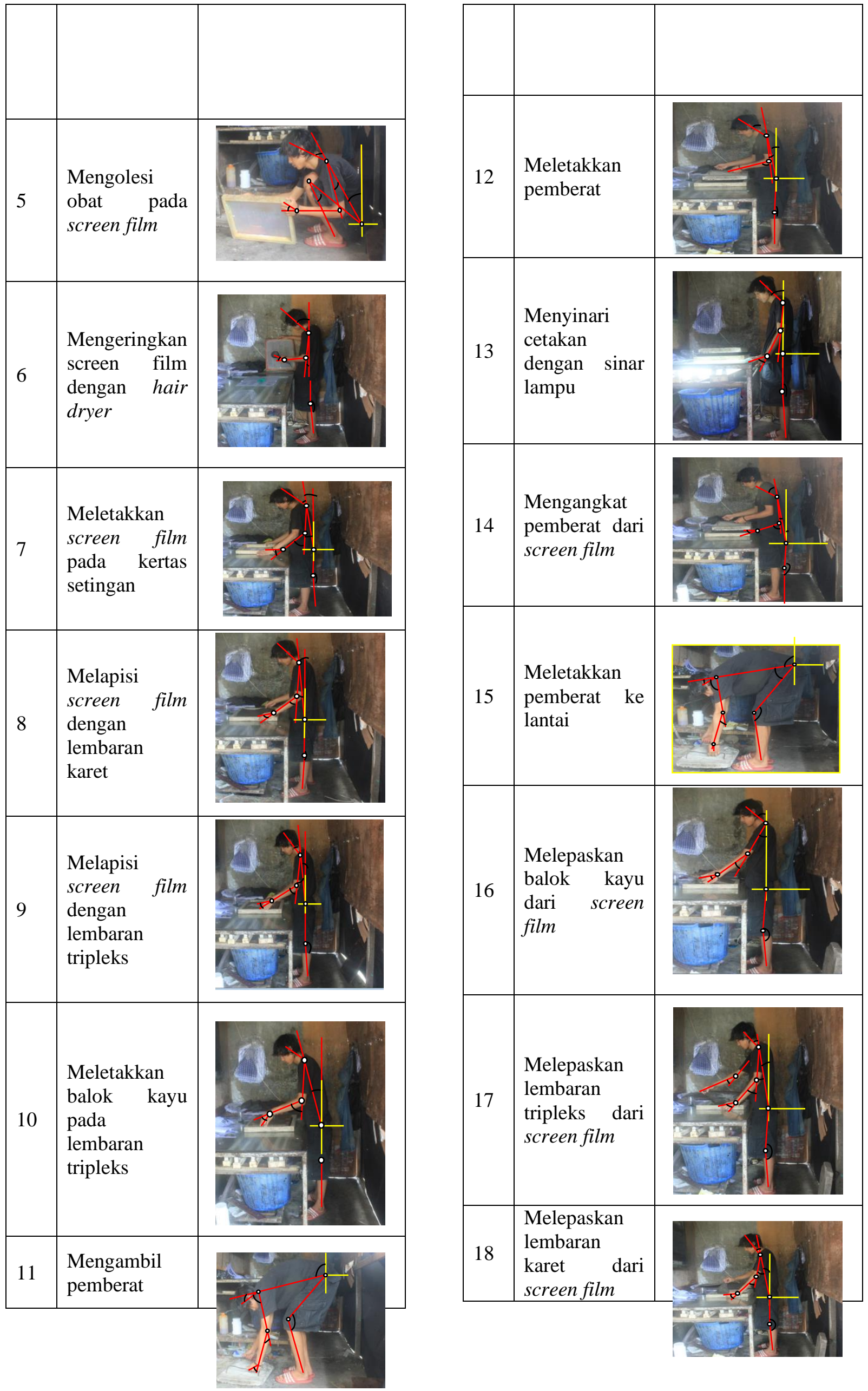


19 \begin{tabular}{l|l|l|}
\hline 19 & $\begin{array}{l}\text { Membawa } \\
\text { screen film ke } \\
\text { tempat } \\
\text { pencucian }\end{array}$ \\
\hline 20 & $\begin{array}{l}\text { Mencuci } \\
\text { screen film } \\
\text { yang sudah } \\
\text { siap }\end{array}$ \\
\hline
\end{tabular}

Dengan menggunakan metode REBA untuk menentukan level risiko cedera MSDs pada operator pada setiap elemen kerja diperoleh hasil seperti yang terdapat pada Lampiran 1.

Hasil analisis dengan menggunakan REBA yang menunjukkan bahwa aktivitas mengangkat dan menurunkan pemberat merupakan elemen kerja dengan tingkat risiko cedera MSDs tertinggi. Hal ini dikarenakan pada saat melakukan aktivitas tersebut posisi tubuh operator dalam keadaan membungkuk hampir $90^{\circ}$ yang diperparah dengan beban yang berat $(150 \mathrm{~N})$ dan pegangan (coupling) yang buruk. Oleh karena itu dirancang alat bantu berupa meja, kursi dan lori. Alas meja terbuat dari kayu dan kaca. Alas yang terbuat dari kayu akan dijadikan tempat peletakan lori yang berisi pemberat, sementara alas yang terbuat kaca didesain untuk proses penyinaran lampu. Dengan alat bantu ini, operator tidak perlu membungkuk untuk mengangkat pemberat untuk ditempatkan pada screen film, tetapi yang dilakukan adalah menggeser lori yang berisi pemberat kepada screen film. Adapun dimensi tubuh yang diperlukan untuk perancangan alat bantu tersebut adalah tinggi siku duduk (TSD), tinggi popliteal (TPo), lebar pinggul (LP), panjang paha (PP) dan tinggi bahu duduk (TBD)

Uji keseragaman, kecukupan, dan kenormalan data untuk dimensi tubuh tersebut seperti terlihat pada Tabel 3, 4 dan 5 berikut.

Tabel 3 Uji Keseraman Data

\begin{tabular}{|c|c|c|c|c|c|}
\hline Item & $\overline{\boldsymbol{X}}$ & STDEV & BKA & BKB & Ket. \\
\hline TSD & 72,87 & 4,63 & 82,15 & 63,59 & Seragam \\
\hline PP & 45,42 & 2,24 & 49,90 & 40,95 & Seragam \\
\hline
\end{tabular}

\begin{tabular}{|c|c|c|c|c|c|}
\hline TPo & 44,07 & 2,92 & 49,93 & 38,23 & Seragam \\
\hline LP & 31.88 & 1,71 & 35,30 & 28,46 & Seragam \\
\hline TBD & 49,90 & 4,54 & 58,97 & 40,83 & Seragam \\
\hline
\end{tabular}

Tabel 4 Uji Kecukupan Data

\begin{tabular}{|c|c|c|c|c|c|}
\hline Item & $\sum \boldsymbol{X}$ & $\sum \boldsymbol{X}^{\mathbf{2}}$ & $\mathbf{N}$ & $\mathbf{N}$ & Ket. \\
\hline TSD & 3279,3 & 239920,3 & 45 & 7 & Data Cukup \\
\hline PP & 1998,6 & 90997,2 & 44 & 4 & Data Cukup \\
\hline TPo & 2115,7 & 93655,75 & 48 & 7 & Data Cukup \\
\hline LP & 1243,4 & 39753,18 & 39 & 5 & Data Cukup \\
\hline TBD & 2245,60 & 112965,86 & 45 & 13 & Data Cukup \\
\hline
\end{tabular}

Tabel 4 Uji Kenormalan Data

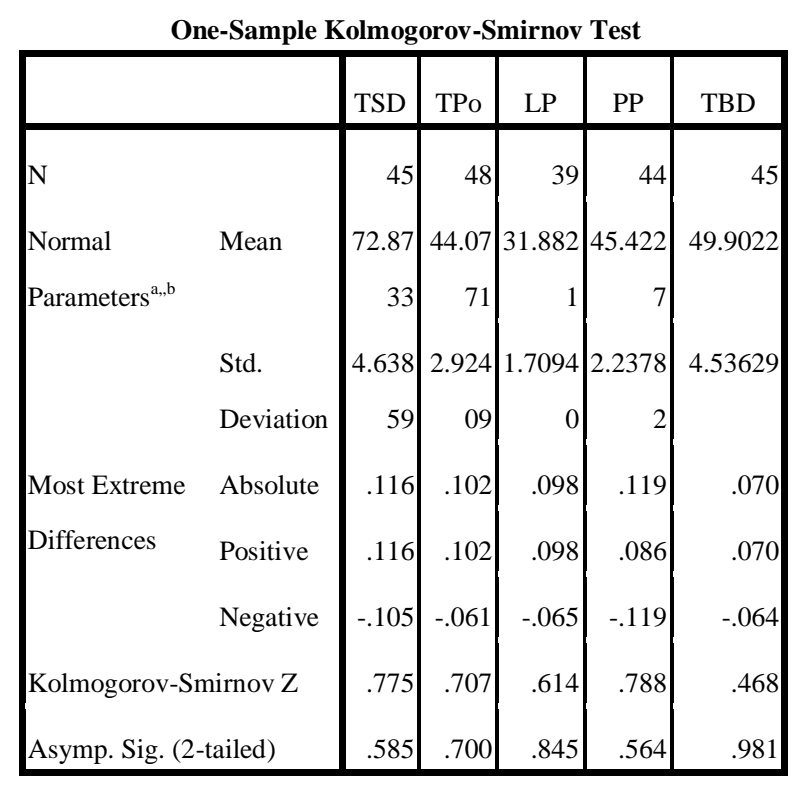

a. Test distribution is Normal.

b. Calculated from data.

Adapun perancangan alat bantu lori yang diusulkan pada penelitian ini dapat dilihat pada Gambar 4 berikut ini.
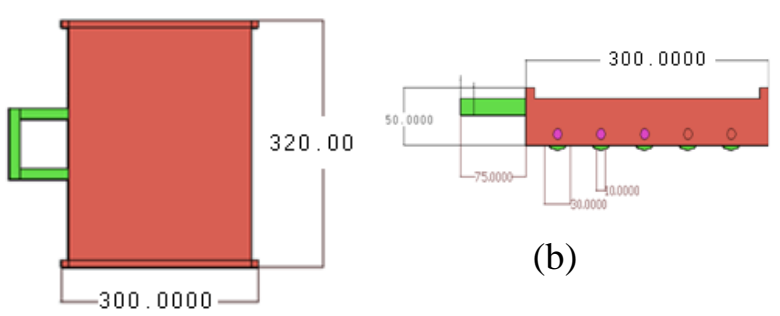

(b)

(a)

Gambar 2 Desain alat bantu lori.

(a) Tampak Atas, (b) Tampak Samping

Adapun perancangan alat bantu meja yang diusulkan pada penelitian ini dapat dilihat pada Gambar 5 berikut ini. 


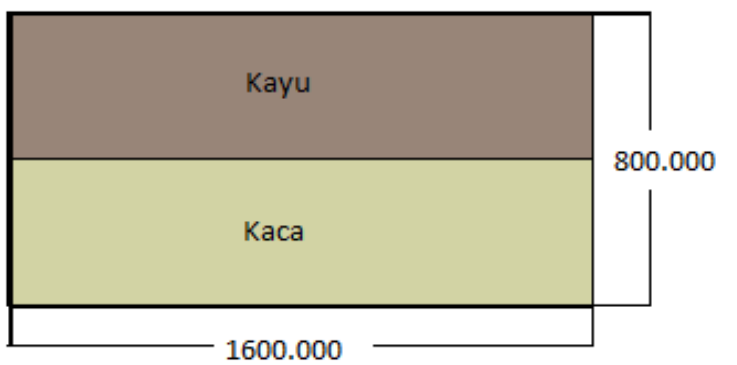

(a)

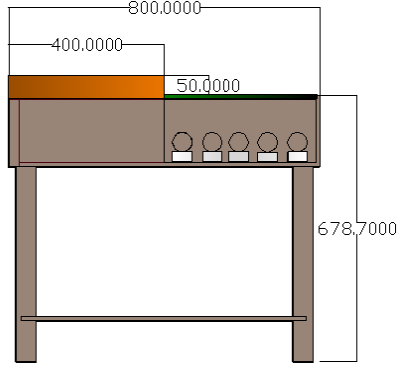

(b)

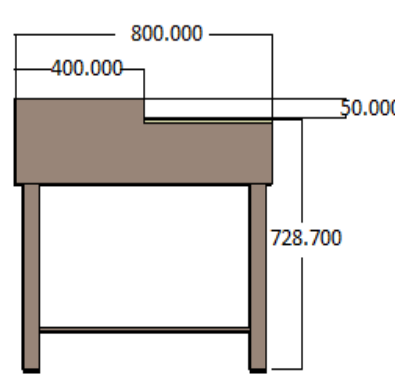

(c)
Gambar 5 Desain Alat Bantu Meja

(a) Tampak Atas, (b) Tampak Potongan,

(c) Tampak Samping

Adapun perancangan alat bantu kursi yang diusulkan pada penelitian ini dapat dilihat pada Gambar 6 berikut ini.

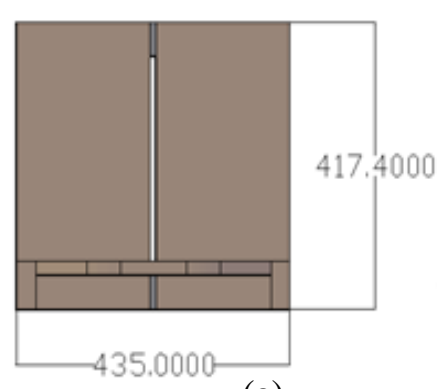

(a)

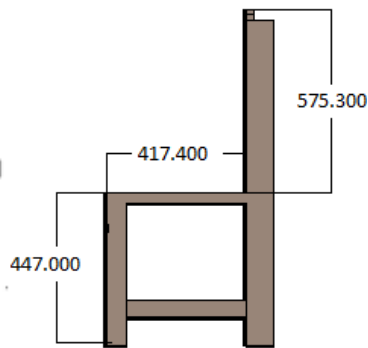

(b)
Gambar 6 Desain Alat Bantu Kursi

Dengan menggunakan alat bantu tersebut, maka terjadi perubahan metode kerja yang dari sebelumnya. Pada perancangan usulan tidak lagi terdapat kegiatan mengangkat dan menurunkan pemberat yang menyebabkan operator membungkuk, melainkan cukup menggeser lori saja. Dengan menggunakan software mannequin pro, dilakukan simulasi metode kerja baru sehingga diperoleh perbandingan level risiko cedera musculoskeletal aktual dan usulan (Gambar 7).
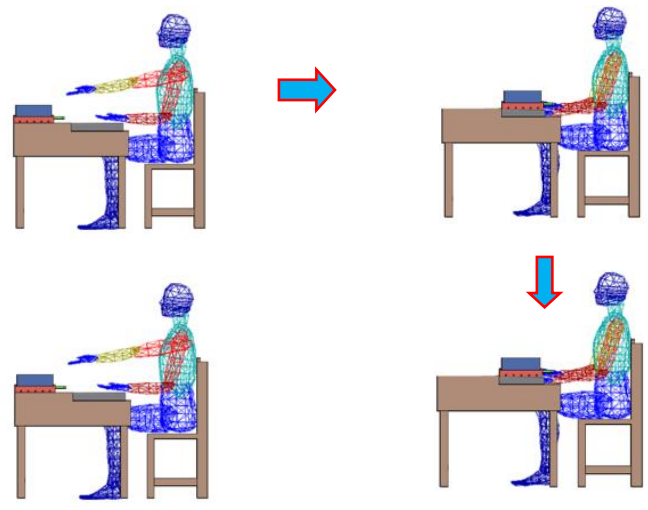

Gambar 7. Simulasi Usulan Perbaikan dengan Menggeser Lori/Pemberat

Pada rancangan perbaikan usulan, terdapat perubahan metode kerja. Adapun perbandingan perubahan metode kerja aktual dan usulan dapat dilihat pada Tabel 5 berikut ini:

Tabel 5. Perbandingan Metode Kerja Aktual dan Usulan

\begin{tabular}{|l|l|}
\hline \multicolumn{1}{|c|}{ Aktual } & \multicolumn{1}{|c|}{ Usulan } \\
\hline $\begin{array}{l}\text { Operator mengambil } \\
\text { pemberat dari lantai }\end{array}$ & $\begin{array}{l}\text { Operator menjangkau } \\
\text { box trolley yang berisi } \\
\text { pemberat }\end{array}$ \\
\hline $\begin{array}{l}\text { Operator mengangkat } \\
\text { pemberat dari lantai } \\
\text { ke meja kerja }\end{array}$ & $\begin{array}{l}\text { Operator menjangkau } \\
\text { box trolley }\end{array}$ \\
\hline $\begin{array}{l}\text { Operator meletakkan } \\
\text { pemberat di atas } \\
\text { screen film pada meja } \\
\text { kerja }\end{array}$ & $\begin{array}{l}\text { Operator menarik box } \\
\text { trolley tepat di atas } \\
\text { screen film. }\end{array}$ \\
\hline $\begin{array}{l}\text { Operator mengambil } \\
\text { pemberat dari meja } \\
\text { kerja }\end{array}$ & $\begin{array}{l}\text { Operator } \\
\text { handle box trolley yang } \\
\text { berisi pemberat }\end{array}$ \\
\hline $\begin{array}{l}\text { Operator mengangkat } \\
\text { pemberat dari meja } \\
\text { kerja ke lantai }\end{array}$ & $\begin{array}{l}\text { Operator memegang } \\
\text { handle box trolley }\end{array}$ \\
\hline $\begin{array}{l}\text { Operator meletakkan } \\
\text { pemberat di lantai }\end{array}$ & $\begin{array}{l}\text { Operator mendorong box } \\
\text { trolley tepat di atas } \\
\text { screen film. }\end{array}$ \\
\hline
\end{tabular}

Setelah simulasi dilakukan, dilakukan kembali penilaian postur kerja operator dengan menggunakan metode REBA. Dari rancangan usulan tersebut, maka terdapat 15 elemen kegiatan yang mengalami penurunan risiko kerja. Adapun elemen kegiatan yang mengalami penurunan risiko tersebut adalah meletakkan kertas setingan pada meja kerja, mengolesi kertas setingan dengan minyak, 
mengambil screen film, mengambil obat (ulano), mengolesi obat pada screen, mengeringkan screen dengan hair dryer, meletakkan screen film pada kertas setingan, melapisi screen film dengan lembaran karet, melapisi screen film dengan lembaran tripleks, mengambil pemberat, meletakkan pemberat pada screen film, menyinari cetakan dengan sinar lampu, mengangkat pemberat dari screen film, meletakkan pemberat ke lantai, melepaskan balok kayu dari screen film, melepaskan lembaran tripleks dari screen film dan melepaskan lembaran karet dari screen film. Perbandingan nilai REBA operator antara kondisi kerja aktual dan setelah perbaikan dapat dilihat pada Lampiran 2.

\section{Kesimpulan dan Saran}

Berdasarkan hasil pengolahan data dan analisis pemecahan masalah dapat diambil kesimpulan sebagai berikut:

1. Hasil evaluasi level risiko cedera MSDs operator stasiun pembuatan film adalah sangat tinggi dan diperlukan tindakan perbaikan sekarang juga.

2. Tindakan perbaikan dilakukan dengan merancang meja, kursi dan lori sesuai dengan dimensi tubuh operator.

3. Terdapat 15 elemen kegiatan yang mengalami penurunan level risiko dan level tindakan dinilai dari postur kerja.

4. Hasil simulasi yang dilakukan pada usulan perancangan diperoleh bahwa usulan perbaikan tersebut mampu menurunkan risiko cedera MSDs.

\section{Daftar Pustaka}

Anggraini W dan Pratama AM, 2012. 'Analisa postur kerja dengan menggunakan metode ovako working analysis system (OWAS)'. Jurnal Sains, Teknologi dan Industri. Vol.10, hlm. 10-18.

Ansari N.A dan Sheikh MJ, 2014. 'Evaluation of work posture by RULA and REBA'. Journal of Mechanical and Civil Engineering. Vol.11, hlm. 18-23.

Hignett S, McAtamney L, 2000. 'Rapid Entire Body Assessment (REBA)'. Applied Ergonomics. Vol.31, hlm. 201-205

Istighfaniar K dan Mulyono, 2016. 'Evaluasi postur kerja dan keluhan muskuloskeletal pada pekerja instalasi farmasi'. The Indonesian Journal of Occupational Safety and Health'. Vol.5, hlm. 81-90

Niekerk SM, Louw Q, Vaughan C, Somers KG, dan Schreve K, 2008. 'Photographic measurement of upper body sitting posture of high school students: A reliability and validity study'. BMC Musculoskeletal Disorders. Vol.9.

Siddiqui NA dan Chacko AG, 2015 'study of the ergonomomics of the workers using the rapid entire body assessment technique on agri-machinery industry. International Journal on Occupational Health \& Safety, Fire \& Environment. Vol.4, hlm. 001-004.

Simanjutak, Risma Adelina, 2007. Analisis Gerakan Repetitive dengan Metode OCRA. Yogyakarta. Institut Sains dan Teknologi APKRIND.

Tarwaka, dkk, 2004. Ergonomi untuk Keselamatan, Kesehatan Kerja, dan Produkstivitas. Surakarta: UNIBA Press. 


\section{Lampiran 1}

Level Risiko Cedera MSDs Operator Aktual

\begin{tabular}{|c|c|c|c|c|}
\hline \multirow{2}{*}{$\begin{array}{c}\text { Elemen } \\
\text { Gerakan no. }\end{array}$} & \multicolumn{4}{|c|}{ Skor REBA } \\
\hline & Kanan & Tindakan & Kiri & Tindakan \\
\hline 1 & 6 (Sedang) & Perlu perbaikan & 6 (Sedang) & Perlu perbaikan \\
\hline 2 & 6 (Sedang) & Perlu perbaikan & 9 (Tinggi) & Perlu perbaikan \\
\hline 3 & 10 (Tinggi) & Segera perbaikan & 6 (Sedang) & Segera perbaikan \\
\hline 4 & 9 (Tinggi) & Segera perbaikan & 7 (Sedang) & Perlu perbaikan \\
\hline 5 & 10 (Tinggi) & Segera perbaikan & 8 (Tinggi) & Segera perbaikan \\
\hline 6 & 11 (Tinggi) & Segera perbaikan & 10 (Tinggi) & Segera perbaikan \\
\hline 7 & 5 (Sedang) & Perlu Perbaikan & 5 (Sedang) & Perlu Perbaikan \\
\hline 8 & 5 (Sedang) & Perlu Perbaikan & 5 (Sedang) & Perlu Perbaikan \\
\hline 9 & 5 (Sedang) & Perlu Perbaikan & 5 (Sedang) & Perlu Perbaikan \\
\hline 10 & 4 (Sedang) & Perlu Perbaikan & 4 (Sedang) & Perlu Perbaikan \\
\hline 11 & $\begin{array}{l}13 \text { (Sangat } \\
\text { tinggi) }\end{array}$ & Sekarang juga & $\begin{array}{l}13 \text { (Sangat } \\
\text { tinggi) }\end{array}$ & Sekarang juga \\
\hline 12 & $\begin{array}{c}10 \\
\text { (tinggi) }\end{array}$ & Segera perbaikan & 10 (tinggi) & Segera perbaikan \\
\hline 13 & 6 (Sedang) & Perlu Perbaikan & 6 (Sedang) & Perlu Perbaikan \\
\hline 14 & 8 (Tinggi) & Segera perbaikan & $\begin{array}{c}8 \\
\text { (Tinggi) }\end{array}$ & Segera perbaikan \\
\hline 15 & $\begin{array}{l}13 \text { (Sangat } \\
\text { tinggi) }\end{array}$ & Sekarang juga & $\begin{array}{l}13 \text { (Sangat } \\
\text { tinggi) }\end{array}$ & Sekarang juga \\
\hline 16 & 8 (Tinggi) & Segera perbaikan & 8 (Tinggi) & Segera perbaikan \\
\hline 17 & $\begin{array}{c}6 \\
\text { (Sedang) }\end{array}$ & Perlu Perbaikan & 5 (Sedang) & Perlu Perbaikan \\
\hline 18 & $\begin{array}{c}8 \\
\text { (Tinggi) }\end{array}$ & Segera perbaikan & 7 (Sedang) & Perlu Perbaikan \\
\hline 19 & 4 (Sedang) & Perlu Perbaikan & 4 (Sedang) & Perlu Perbaikan \\
\hline 20 & 9 (Tinggi) & Segera perbaikan & 9 (Tinggi) & Segera perbaikan \\
\hline
\end{tabular}




\section{Lampiran 2}

Perbandingan nilai REBA Antara Kondisi Kerja Aktual dan

Setelah Perbaikan

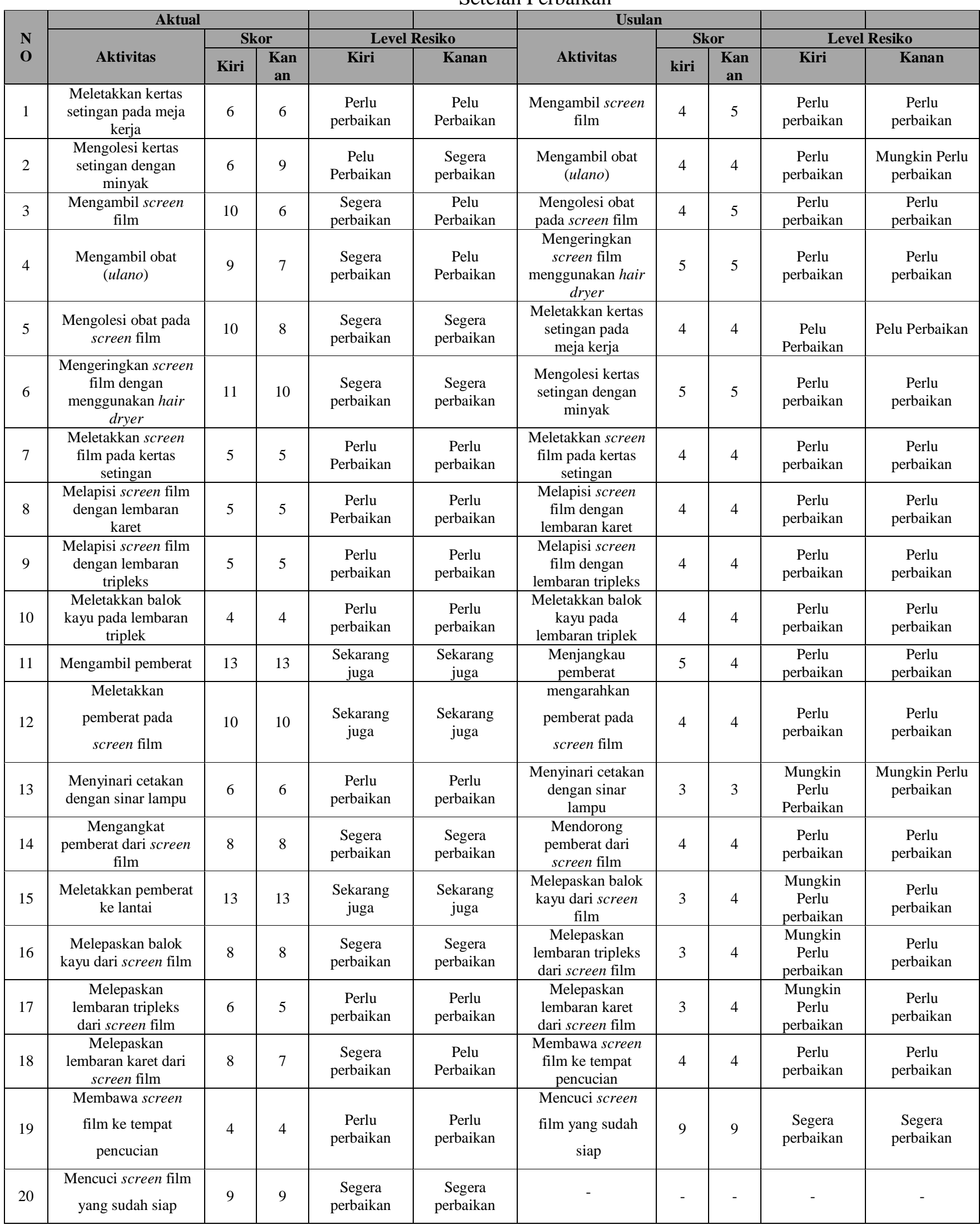

